\title{
Care work an diffusion of innovation in Danish elder care
}

\author{
Luise Li Langergaard* \\ Department of People and Technology \\ Roskilde University, Roskilde, Denmark \\ Email: luiseli@ruc.dk \\ ${ }^{*}$ corresponding author
}

\begin{abstract}
This article explores the interplay between different types of knowledge and rationality in care work through a case study of a nursing home innovation project in a Danish municipality. The aim is to understand the implications for innovation processes and dissemination within the context of elder care. Care work, in some sense, relies on relational and contextual knowledge which may lead to challenges when innovation and best practices are to be diffused across organizations. This is especially true since diffusion often relies on codification of practices and knowledge. Caring rationality is essential to how technologies and methods are practiced in the care situation, and thus also essential for best practices and how they are disseminated. However, other types of codified and explicit rationality are equally important. The article concludes that there are several types of knowledge in play in care work practices and innovation, and it indicates that communities of practice could be key to understanding how to share and learn from best practices across organizations.
\end{abstract}

Keywords: Public sector innovation, elder care, knowledge sharing, care work, Denmark

\section{Introduction}

In Scandinavian welfare states, elder care is a core welfare domain which, to a large extent, is provided by the public sector (Daly \& Lewis, 2000). The right of elderly citizens to have care provided in order to have a decent life and wellbeing in later age is not contested as an overall welfare state responsibility (Knijn \& Kremer, 1997). However, ageing populations and increased lifespan, combined with financial pressure on the public sector, make the question of how to ensure efficient elder care a major policy concern. Another central issue is how quality of life and ethical standards are upheld in elder care institutions and organizations in general and under these particular circumstances. One widespread answer to these challenges is to initiate innovative efforts in the public sector in order to meet the desired level of welfare today and in the future under conditions of changing demographics and increasing demands on the quality and flexibility of public services (Bason, 2007; Fuglsang \& Rønning, 
2014; Moltesen \& Dahlerup, 2007; Rådet for Teknologi og Innovation, 2008; Tanggaard \& Wegener, 2015).

This has led to political strategies and initiatives to enhance innovative efforts and find new solutions to increase the effectiveness and quality of elder care. In Danish elder care, for example, this manifests itself as a political interest in diffusion of innovation and learning from best practice across the sector. This article studies an innovation project in the municipality of Copenhagen, which involves developing and sharing of innovation across five nursing homes. An aim of the project is to develop a 'catalogue of methods', which will function as a tool for sharing best practices and for harvesting ideas from successful local practices. Under the project, the nursing homes have received funds to systematically experiment with activities aimed at increasing citizens' quality of life. Each nursing home has the autonomy to choose activities with which they wish to work. Some nursing homes have experimented with 'interview techniques' as a method by which to gain a better understanding of the citizens' lives. Others have experimented with tablets as a tool to create 'special moments' for the citizens, and also with a 'buddy arrangement', where new residents are greeted by one of the other residents when they move in. These innovations all emerge from everyday work practice in the specific local contexts of the respective nursing homes.

The endeavour to diffuse and spread innovation in the public sector to a wider population of organizations is linked to the pursuit of allowing society to benefit from innovation in the broadest possible sense. This can be seen in contrast to protecting innovations in order to maintain a competitive advantage, as is the case in the private sector (Hartley, 2005, 2016). There seems to be a growing recognition that diffusion of innovation and spreading of best practice often rely on cultural and tacit dimensions of knowledge (Hartley \& Benington, 2006). Despite these insights, many innovation projects in the public sector still seem to rely on a concept of knowledge as codified and explicit, and innovation as something which can be replicated from one organization to another. It is often assumed that public service organizations will share their knowledge through benchmarking, integrated databases, websites and collaboration, even when there is no clear strategy for knowledge transfer and no articulated theory of what knowledge is and how it can be shared (Hartley \& Benington, 2006). A similar tendency is seen with the case study of this article, where there is an aim to develop a 'catalogue of methods' and to spread innovations across organizations. There are few explicit reflections about how to understand knowledge and learning in the context of elder care work, or what this means for processes and diffusion of innovation. Theoretically, care work is often conceptualized as highly relational and contextual, as characterized by a socalled 'care rationality' (Dybbroe, 2012; Wærness, 1984). From a perspective of dissemination of practices across organizations or local contexts, not understanding the specifics of care work could create tensions between the contextuality of innovation practices and the requirement for codification and explication of these.

This schism is explored in the article through a study and discussion of how different types of knowledge and rationality play out in care work practice and what it means for innovation processes. Subsequently, the article discusses the implications of different types of knowledge and learning for dissemination of innovation in elder care within a public sector context. The focus is on everyday work practices and the implications of these for innovation processes; not least because they are seen to have implications for the dissemination and adoption of practices in other contexts. The contribution of this article is a contextualization of public service innovation in the domain of elder care, which 
elucidates the interrelationship between the contextual and relational character of formal paid care work and more systematic, formal and codified types of knowledge. The insights are particularly relevant to professional care in the public service domains of care work, such as nursing, elder care and child care.

\section{Diffusion of innovation: between replication and learning}

There is currently a great political interest in the role of diffusion or dissemination of innovation in the public sector. In Rogers' contribution to understanding diffusion of innovation, he argues that an important factor for the adoption rate of innovation is its compatibility with the values, beliefs and experiences of the individuals in the social system (1995). Recently, the recognition of the role of context and culture for diffusion of innovation has led researchers to reconsider ideas about dissemination and adoption of innovation and to dismiss concepts like replication (Hartley \& Benington, 2006). Hartley and Benington (2006, p. 104), for example, argue that there may not be a best way to share knowledge and that perhaps there has been an overemphasis on explicit knowledge in the public sector. Challenging what they call the 'drag and drop' metaphor of knowledge transfer, (which implies the movement of explicit - abstracted knowledge from one context to another), they suggest instead that knowledge be seen as 'continuously reviewed, recreated and re-appreciated as it is taken into different settings'. Thus, they suggest the metaphor of 'grafting and transplanting', which is an active process rather than a passive copying of best practice. They also suggest that adaption rather than adoption is central to knowledge transfer (Hartley \& Benington, 2006, p. 104), meaning that innovations are often adjusted when implemented in a new organizational context. Hartley (2016) further emphasizes that service innovations, which often require greater tacit knowledge than technological innovations, do not spread linearly and are often adapted to the local context and conditions (Hartley, 2016). These ideas lie well in line with practice based understandings of innovation as well as theories of organizational learning.

Practice based understandings of innovation appear in parts of organizational learning literature, as well as in service innovation literature. They emphasize the role of everyday practice for innovation and break with the assumption that innovation is always intentional and disruptive (Fuglsang \& Sørensen, 2011). Practice based understandings of innovation recognize incremental and less tangible improvements as significant for innovation and as something that may gradually lead to more radical changes (Sundbo \& Toivonen, 2011). From these perspectives, innovation does not rely mainly on explicit and codified knowledge and is not always easily replicable. Concepts like 'ad hoc innovation' (Jong \& Vermeulen, 2003; Toivonen, 2010) and 'bricolage', as well as 'problem-solving with resources at hand' (Brown \& Duguid, 1991; Fuglsang \& Sørensen, 2011), signify that innovation activities are closely integrated into daily practices (Fuglsang, 2008). In other words, they can take place partly as a hidden activity and contain tacit dimensions that are not always acknowledged (Fuglsang \& Sørensen, 2011). A challenge with this kind of innovation is how to systematize it in a way that makes it possible to transfer or disseminate information to other localities or organizations. These concepts of innovation may help us understand innovation processes in this case study. 
The break with abstracted and codified knowledge: organizational learning, situated knowledge and rationality of caring

A break with the strong reliance on abstracted and codified knowledge, and claims of the importance of tacit and practice based types of knowledge, is seen in theories on organizational learning. Organizational learning literature emphasizes the role of situated knowledge, experience and practice for knowledge sharing. Distinctions between explicit and tacit knowledge (Nonaka, 1994), and between abstracted and situated knowledge and learning (Brown, Collins, \& Duguid, 1989), have been unfolded in this literature. Common to these distinctions is an interest in breaking with the prevailing valorization of abstracted and codified knowledge (Brown \& Duguid, 1991). Instead, more practice based understandings of innovation are stressed and communities of practice are seen as important sites for learning, knowledge sharing and innovation in organizational settings (Brown \& Duguid, 1991). According to Wenger (2000), it is by participating in such communities that professionals define with each other what constitutes competence in a given context, such as determining what defines a reliable doctor or what defines a gifted photographer.

Another group of theories that break with abstracted knowledge are theories on care rationality. Here the distinction is presented as one between scientific, instrumental rationality versus expressive, emotional rationality (Wærness, 1984). Organizational theory has paid little attention to the type of knowledge that rationality of caring represents. However, it has been widely debated in feminist theories of care and theory on care work (Davies, 1995; Dybbroe, 2012; Parton, 2003; Wærness, 1984), and also concerning the relationship between justice and care (Friedman, 1995; Habermas, 1990; Okin, 1989). Theories about knowledge in care work with dichotomies between caring and science and between abstract versus situated knowledge. Wærness also distinguishes between the cognitive versus sentient actor (1984) and valorizes the sentient actor over the cognitive when it comes to care work. The characteristics of care work are central to understanding the everyday practices in nursing homes. Care rationality is represented as a relational and contextual rationality combined with a high level of empathy. It implies that the assessment of what should be done in a certain situation is based on knowledge of the citizen and understanding of his or her situation. This rationality is central to the meaning of care work and, thus, to the practices in everyday care situations in nursing homes. Dybbroe (2012) describes that meaning and identity in care work are given in situations when care workers interpret and understand the situation of the other and are able to organize tasks and do them in a particular way. The specific experiences and interactions with the other are key to this meaning. In human work, the citizens, patients or clients involved are a significant dimension of interactions in work, and professional identity is saturated with understanding, reflection and experiences of interacting with human beings (Dybbroe, 2012). This elucidates the ethical dimensions in care work, which have been conceptualized in care ethics (Gilligan, 2009) and in literature on ethical literacy in care work (Krøjer \& Dupret, 2015). Care ethics focus on caring ability as a fundamental competence we acquire through our history as caregivers (Kamp \& Hvid, 2012). It is contextual and relational ethics that link to experience and practical reason developed from particular situations, rather than universal principles of ethics (Gilligan, 2009).

The concepts of care ethics and care rationality have normative underpinnings these concepts aim at valorizing ways of reasoning that have been devalorized in hierarchical dichotomies between body and rationality, female and male, private and public, and between particular and universal in relation to knowledge 
or ethical judgement (Bacchi \& Beasley, 2002; Dahl, 2012; Parton, 2003; Young, 1989). However, this concept of care has been challenged and nuanced in theoretical debates, such as debates about justice and care, and in debates about care and rights in a disability context. In disability studies, the discussion and critique of the concept of care, especially regarding its implications for dependency and asymmetry in power relations (Kröger, 2009), argue that this makes empowerment and care incompatible (Kröger, 2009; Morris, 1997, 2001). Further, it is argued that the language of and policy-focus upon 'care' tends to be oppressive and objectifying (Fine \& Glendinning, 2005). In feminist debates about justice and care, it is sometimes argued that we need to rethink the relationship between justice and care in ways that integrate or reconcile the two (Friedman, 1995; Held, 1995).

\section{Formal paid care as professional practice}

Relevant to this article is the view on care in the field of formal paid care work, such as that in a welfare state setting. Here, the concept of care is developed within a framework of competencies and professional practice, sometimes in ways that break with a dichotomized view on care as something opposed to or separate from scientific knowledge. Davies (1995) argues that care work is characterized by flexibility of response to what is required in the situation, where nothing is predictable in advance and care is 'committed attending' which cannot easily be translated into a set of specific and identifiable tasks. However, her view also represents an understanding of care that challenges dichotomous thinking, counterposing the head with the heart and rationality with emotion. It imparts a rather purposeful, active and 'rational' love as the essence of caring. It is not about contrasting competence and caring, instead but rather to see viewing it as competence in caring (Davies, 1995, p. 19). Furthermore, she stresses that formal knowledge, such as scientific knowledge, stands alongside other types of knowledge and leaves considerable space for adjustment and negotiation in the caring situation in light of acquired and detailed understanding of people and situations (Davies, 1995). This suggests that we can see caring as produced by and supported through a variety of knowledge forms.

When dealing with formal paid care work in a welfare state setting, care recipients are also characterized as being citizens with rights. From a normative perspective, the public sector is structured by a particular principle of justice and relates to citizens as rights bearing persons (Eriksen, 1999; Langergaard, 2011; Rothstein, 1998). But even beyond this particular normative definition of the public sector, one can argue that due process and individual rights are important formal principles that, in some instances, cannot be bypassed by relational and sentient concerns. Some argue that values of equal treatment, impartiality, predictability and fairness in the handling of cases, alongside a concern for due process, are important in the public sector (du Gay, 2008), thus putting a limit on the scope of the ethics of care and opening an additional dimension to be balanced in the daily practice of care work.

\section{Methodology and the case study}

This article builds on a qualitative case study of an innovation project called 'Quality of life at Nursing Homes' in the Municipality of Copenhagen. The data were collected between spring 2015 and autumn 2016. This particular project encompasses local sub-projects at five nursing homes; they receive funds from the municipality to carry out innovative activities with the aim of improving

NJSR - Nordic Journal of Social Research 
citizens' quality of life. The resources are used to give employees extra time to work on the activities, on consultancy aid and to buy technology. Each nursing home has a local project group and has the autonomy to define the focus and aims of their activities. This opens up a complementarity between top-down structure and bottom-up practice in the project as a whole, and makes the case relevant for studying the conditions around disseminating and spreading innovation across local organizations in the sector. All nursing homes couple the project with currently existing focus areas of their activities and allow these to determine the foci of their local sub-projects. The innovation activities that they experiment with are mostly non-technological and directed at improving the self-determination of the citizens or the relational aspects of the citizens' lives. The activities range from new human practices to the use of information and digital technology. These include activities such as a 'buddy arrangement', where new residents are greeted by a neighbour responsible for welcoming them and establishing initial contact, the systematic use of interview techniques, or the deployment of tablets to support the relationships between staff and residents by creating 'special moments'. The latter method is used in particular with cognitively impaired citizens who have difficulties with articulating how their quality of life can be improved. The project is about both creating innovation in the sense of new practices and making already existing best practices visible in order to let other nursing homes learn from them.

\section{Table 1: Overview of innovation activities}

\begin{tabular}{|l|ll|}
\hline Nursing home 1 & - & $\begin{array}{l}\text { Neighbourliness (internally between residents and with } \\
\text { external local community). }\end{array}$ \\
& - & $\begin{array}{l}\text { Role models in relation to meals (such as the role of } \\
\text { hostess). }\end{array}$ \\
Nursing home 2 & - & Collaboration between different professional groups. \\
\hline Nursing home 3 & - & $\begin{array}{l}\text { 'Special moments' of spontaneous presence, } \\
\text { sometimes supported by tablets or musical instruments. } \\
\text { Fursing home 4 }\end{array}$ \\
& - & $\begin{array}{l}\text { Focus on citizens with dementia. } \\
\text { Life stories, sometimes supported by technology such } \\
\text { as tablets. }\end{array}$ \\
\hline Nursing home 5 & - & $\begin{array}{l}\text { Debate groups in combination with dinner. } \\
\text { 'The good life': action plans developed by use of certain } \\
\text { interview techniques. Focus on homeliness and the } \\
\text { citizen's understanding of the good everyday life. }\end{array}$ \\
& $-\begin{array}{l}\text { 'Your choice, your life': an interview technique focusing } \\
\text { on the citizen's notions of the good life. } \\
\text { 'Moving in' well: a buddy arrangement for new residents } \\
\text { who are greeted by a neighbour. }\end{array}$ \\
\hline
\end{tabular}

This article builds on group interviews carried out with care assistants, nurses and managers at the five nursing homes. The interviews were conducted in two rounds: the first round was in spring 2015 in the early days of the project, where a combined total of six interviews from all five nursing homes were conducted. A total of 13 employees and leaders participated in the interviews, which lasted between one and one-and-a-half hours each. The interviews were exploratory with the aim of gaining insight into innovation processes in the particular setting and context of the nursing homes, and gaining insight into the role of everyday practice and top-down project structures for innovation processes. The interview guide was centred around themes such as: details about the local sub-projects and the backgrounds for and decisions made in relation to these, how changes are initiated at the nursing homes, challenges and resources in relation to the 
innovation projects and the relationship between the overall municipal project and the everyday practices and activities.

The second round of interviews, conducted in autumn 2016, consisted of six follow-up interviews aimed at covering how the project had developed and the results the nursing homes experienced in relation to it. These interviews also lasted between one and one-and-a-half hours each. The interview guide had themes like: the innovation process so far, the results of the initiatives, the relationship between the sub-project and the overall project, the role and relationship with the citizens and their ideas about future retention of the efforts and potential adoption of methods from other nursing homes. Interviews were conducted with a total of 18 employees and leaders, some of whom had also participated in the first round.

All interviews were qualitative and semi-structured (Kvale, 2007), and were conducted in groups of care assistants, nurses and leaders. This approach allowed the interviewees to express their own perspectives and let the conversation develop in ways where the interviewees could introduce themes they perceived as important to the project and their everyday work practices. In looking at the differences between the nursing homes and the local subprojects, one recurring theme in the stories about everyday work life and practices was the meaning of care and the relational dimension of care work. Even though the interviewees were not asked directly about care, their answers consistently reflected that care and their relationships with citizens were perceived to be central to their everyday work. Thus, the meaning of care is pivotal to the success of the project and its goal of working systematically to increase citizens' quality of life. It is this particular dimension of everyday practices that will be discussed in relation to its implications for innovation processes and organizational learning within the context of public sector nursing homes.

The nursing home managers selected particular employees for interview because they considered them most able to provide insight into the project. This potentially led to issues due to the managers' positions as gatekeepers. However, as the aim was not an evaluation of the project, something which could have led to self-censorship of the employees, but rather to understand how they make sense of the project in relation to their everyday work life, this issue did not come across as relevant.

In the analysis, emphasis was placed on statements by care assistants and nurses, as they are closest to the everyday practices and methods used to work with citizens. No particular differences between these two groups of care workers were revealed in the interviews regarding the way they portray care work or the competencies and skills necessary for carrying out care work; both groups are similar in the sense that they explicitly emphasize the importance of relations and empathy while at the same time stressing professionalism and knowledge about dementia. The analysis displays how the nursing homes work to systematize and codify certain dimensions of care in order to better share knowledge and understanding about the citizens. A thematic analysis was used with a focus on the theme of care and the types of knowledge at play in the practices that are developed through the project. Quotations have been selected that demonstrate these issues as expressed by the employees. 


\title{
Findings and analysis: the 'quality of life at nursing homes' project
}

In a review of the interviewees' responses, the dimensions of care work in relation to the identity and meaning of this work is expressed as being of central importance. To the employees, an essential part of care work has to do with building a relationship with the elderly citizens. In both the first and second rounds of interviews, employees expressed that in order for innovations to be successful, citizens must be approached with care, empathy and understanding. Across almost all interviews, the relationships with citizens are stated as a primary motivating factor in choosing the care worker profession. One care worker says:

\begin{abstract}
'Most people who apply for this job are not too concerned with leaving at precisely one o'clock [...] That is how it is when you deal with people. [It's about] empathy, caring and an interest in how other people live their lives and how they feel. You get very affected by how the residents feel' (care assistant in nursing home, first round of interviews).
\end{abstract}

A number of the innovations that are developed in the project seem to focus on supporting this dimension of care work.

Contrary to what is often stressed in literature on care, namely that the competencies and rationality connected to care work are often difficult to articulate (Davies, 1995) and thus easier to overlook, the nurses and care assistants in the interviews are very explicit about that particular dimension of their work. The relational and empathic aspects of work were the foremost thoughts in their minds when asked about their activities in the innovation project. Upon closer inspection, however, it appears that while the formal dimensions, in terms of the frame of the project and professional care competencies, are clearly important, they are not the only factors in play here; other types of professional knowledge are equally significant to the care workers and their work within the project. The following section will demonstrate this point by indicating how the care workers portray their understanding of the situational and relational dimensions of their work, how they attempt to systematize these dimensions through the project methods, and how other professional competencies and skills come into play alongside caring rationality.

\section{Attempts to systematize and support care relations}

The innovation project constitutes a frame where relational dimensions are codified and systematized in a way that makes it possible to deal with them in more explicit ways. In this section, two examples of methods from the project shall be presented. They both illustrate the importance of care rationality in practices aimed at supporting the good life for citizens, but also demonstrate how the work with the innovation project leads to attempts to systematize and formalize certain dimensions of care work. In this sense, it is the interplay between systematic approaches to the innovations, as well as the competency of reading situations and people, that makes the innovation successful and possible to share within the organization. Working with life stories and action plans through the use of interview guides represents ways of sharing (through documentation), codifying and systematizing the relationship with citizens. Providing good care is easier when the care workers know the citizens and their life stories well. Getting the citizen to tell their life stories, however, requires time and trust. A care worker notes that it is often through one-to-one conversations 
with citizens that silent needs are uncovered. It is important to take the time to talk to the citizen and to understand the expression of a need when something turns up in conversation. She explains that very often the things that are most important to the resident are not articulated during encounters with practical purposes and small talk. Working with people implies that you cannot always follow a script or plan all details in advance, however the systematic approach to talking with citizens about their wants and needs works as a way to get closer to the citizens and strengthen the relationship. Care workers also reported that the systematic approach has helped open up new perspectives of the citizens which were not seen before. On the other hand, care workers also stress that it is important to seize the moment with the citizens and be able to understand their needs in that particular moment. Often, major insights occur unexpectedly because the care workers are good at reading the situation and understanding what the citizen wants in that particular moment. In this sense, the use of the interview guide for citizens is supported by the situational competence of the care worker.

Another example is the use of tablets to support the active work with citizens' life stories and to create what they call 'special moments' of spontaneous presence. Tablets are used as a form of technology to support this relationship and aid the establishment of trust and intimacy. For example, the tablets can be used to listen to music that the citizens used to like when they were younger, or to look at locations on Google street view to stimulate the citizens' memories of places where they used to live. A care worker from one of the nursing homes presents a story where she used the tablet with a citizen with dementia who had been very confused one evening. The citizen immediately calmed down when the care worker found a picture of his daughter on the tablet. This good feeling lasted all evening and the citizen remained calm and happy. This, of course, could also be done with a photograph alone, but the tablet has a number of options. The tablet represents a way to systematize and make some of the relational aspects of care concrete and to create certain practices which all care workers can take part in and which can be transferred to other organizations. The use of the tablet, however, relies on situated knowledge and such incidents cannot be fully planned. Especially with citizens with dementia, one cannot know in advance how the citizen will feel on a certain day, so it is about seizing the moment when the citizen is feeling well and is willing to engage. As another care worker says about the citizens who cannot participate in the ordinary activities of the nursing home:

\footnotetext{
'This is for example residents with cognitive impairments, dementia etc. where they can manage something for fifteen minutes and that has to be done here and now, that is not planned, because then they will not be able to do it anyway, because they are not feeling well enough. But here you can see that the resident is feeling well so that you can have a special moment' (care assistant, first round of interviews).
}

Even with the strong dimensions of tacit, situated knowledge in these interactions, there are ways of systematizing and codifying practices to support these dimensions. The rationality of care is constituted through the way care workers conceive of the here and now situation and the needs of the other (Dybbroe, 2012).

There is also an ethical dimension to this, where the care workers make an effort to understand the resident as a concrete other for whom they have a responsibility. The tablet is a new technology put into use in the nursing homes as part of the project, which in itself is a tool or support but cannot be the 
innovation itself. Only through correct use, which requires certain skills that are not part of the script or the manual, can the tablet be successfully used to support the intimacy and good moments with the citizens. This requires care rationality or, in other words, a sensitivity to the resident in order to understand when and how to use the tablet in concrete situations. As Brown and Duguid (1991) point out about manuals, they specify what to do but not why. Similarly, a 'catalogue of methods' may give some suggestions on the technical use of the tablet or the purpose of using it in a care relationship. However, when and how to use it with a particular citizen requires situated knowledge and skills, which also entails ethical, practical reasoning. This might be understood through Krøjer and Dupret's (2015) concept of moral literacy in technological care. Krøjer and Dupret (2015) present examples of nurses using new technologies that affect their relationships with patients by creating a feeling of distance between the nurse and the patient. In order to keep the relationship with the patient as the concrete other and maintain professional standards, nurses develop a moral literacy which helps them navigate and deal with morals and ethics in complex care situations (Krøjer \& Dupret, 2015). The relationship between the care worker and caregiver raises both technical and ethical claims as to the use of technologies, such as the use of a tablet in care work. The competencies to deal with this can be learned and also partly articulated, but it requires experience. If the tablet as a method of best practice is to be transferred or diffused between organizations in the sector, this aspect is essential to understand. This aspect is what determines the adaption and concrete use of it in a new organization, and determines whether the technology will actually support the quality of life of the citizens in nursing homes.

Before ending the analysis, a few remarks shall be made about the types of knowledge and rationality not previously emphasized, but which are also important to the practices of care workers as expressed in the interviews. This analysis indicates that the innovation project supports attempts to codify and systematize care work and its relational dimensions. The importance of empathy and the relational dimensions of care work were prevalent in both rounds of interviews, but other rationalities and types of knowledge became especially clear in the second round of interviews; they will be briefly touched upon here. The aim is to contrast and clarify the different rationalities in formal paid care and to avoid an overemphasis on the local, tacit and contextual dimensions.

An example from the second round of interviews indicates how one of the nursing homes assesses the impact of the innovative activities on citizens. This nursing home focuses specifically on citizens with dementia who have difficulties in articulating their wants and needs. The methods they use are life stories, or 'special moments' of spontaneous presence (sometimes with the help of music), and they use these systematically to share knowledge and experiences about what works well with particular citizens. To make this work, care competencies about reading the citizen in a particular moment, as well as scientific and medical knowledge about dementia, is central. This is central both in regard to the actual activities and in the way that they attempt to document the effect of the innovation methods. They use a set of well-known parameters from science about dementia to assess the effect on citizens' moods, levels of activity and waking states, and keep records about the reactions and development of citizens.

In order for care workers to work effectively with residents with dementia, they must possess a great deal of specialized knowledge about dementia, about rights to due process (e.g., rules for use of force, duty of care, confidentiality and consent, all of which were parameters especially prevalent in the second 
round of interviews), as well as about empathy and caring rationality. As Davies (1995) argues, the formal knowledge works alongside caring competency, and this is revealed through the interviews. The interplay between situational and formal competencies is central to the innovations themselves and the processes through which they are developed.

\section{Adaption and diffusion of innovation in care work}

The study shows that care rationality stands central in care workers' portrayals of their care practices, but it also shows attempts to systematize practices in ways that can be shared. The analysis highlighted the fact that other, more explicit and formal forms of rationality and knowledge, such as scientific rationality and understanding of formal rights to due process, were seen as central to the care workers. Practice based innovations, such as the ones in this case, are key to understanding innovation processes and the conditions for adaption and, consequently, diffusion of innovation between organizations. The interviews indicate that the local practice contexts determine which and how innovations developed in other organizations will be adapted by other organizations. The understanding of both rationality and values are central, as will be argued in this section.

The study indicates that rather than focusing on one type of knowledge in relation to care work practice for processes and diffusion of innovation, it must be understood how various types of knowledge unfold in different situations. There may be value in emphasizing the knowledge dimensions of care as a professional practice, even if it is highly relational. Some theories of care work and care ethics tend to be one-sided, working with a dichotomous representation of care in contrast to other types of knowledge. In the setting of formal, public sector care work, such dichotomous approaches seem to miss the interrelationship between different types of knowledge and underplay the importance of scientific, medical knowledge. This is apparent in the example of working with citizens with dementia and the professional distance required: not only must the care worker ensure equal treatment without favouritism/preferential treatment, but the care worker must also meet the citizen openly in order to read their needs and wishes in regard to their everyday lives. In the second round of interviews, one of the care assistants states how the practices related to the project, specifically the action plan for citizens, have given a more systematic approach to citizens; this has opened new perspectives on how to reach an understanding of what the citizens want. Working with an action plan for each citizen, where notes about the citizen's habits, history and wishes are written down, has revealed new vistas about how the citizens want their everyday activities organized.

One important competency of care workers is to assess the situation and understand what type of knowledge and skills are required, something Davies also indicates with her representation of competency in care (1995). As a contribution to care work research, it can be seen how different rationalities and types of knowledge are in play. As in the examples illustrated, the rationality of caring and the moral literacy in the relationship with citizens is crucial to care work and to judging what type of knowledge is required in each situation. Thus, this study is relevant to innovation processes in that domain, as well as to diffusion of innovation across organizations. The interviews reveal that for care workers there are important values and identities connected to caring and, as the context of caring is one of ethics and values, they also determine the conditions for learning by the care workers and the organizations. 
The second round of interviews touched more directly upon the connection between the different local sub-projects and the possibility of adopting innovations from other nursing homes. The employees expressed that the local anchoring of the sub-projects and the autonomy to define the methods by which to work have been important to them in making sense of the project. This autonomy has allowed new practices to evolve from existing practice and, according to the employees, is important to the potential adoption or adaption of methods developed at other nursing homes. When asked whether they would consider implementing methods presented from the other nursing homes, they agree that they would only consider taking on innovations that fit their local practices, routines and the needs their citizens experience. It seems also that there is an emphasis on adapting and remodelling methods to fit local contexts:

'It is more about the small things rather than large systems. It can be ideas about everything from how to greet a new citizen or how citizens with mutual interests find each other. You can take what you like and adapt it a little and make something new' (care assistant, second round of interviews).

In order to understand diffusion or adoption of innovation in this setting, which is characterized by both scientific, formal knowledge and concern for rights, and by relational and contextual rationality and competence related to care, communities of practice may be a key concept. This is supported by the interviews where it is made clear that sharing of knowledge and experience between the care workers is a central part of implementing and sustaining a focus on the activities. If we acknowledge the role that communities of practice play in knowledge sharing and adaption of innovations and methods, we can avoid the juxtaposition of abstracted knowledge with learning. We can look at 'communities of practice' as central sites for learning and knowledge sharing (Brown \& Duguid, 1991; Wenger, 2000). Communities of practice refer to the specific work practices, which are central for negotiating meaning between participants (Dybbroe, 2012). They are also the communities with certain professional values and norms, which are essential to how care workers make sense of innovations in a 'catalogue of methods'. In relation to care work, communities of practice play a central role in communication about care practices. In the interviews, several care workers refer to internal and external networks for learning and knowledge sharing, which can also be seen as communities of practice. Organizationally, this means that it is through the communities and groups of care workers that new methods will be negotiated and ascribed meaning before they are adapted into practice. Overlooking this may lead to resistance or to a use of technology that does not support the purpose of improving citizens' quality of life. Dahl (2009) and Dahl and Rasmussen (2012) have described how the implementation of standards and procedures, and part of New Public Management, have led to different kinds of resistance at the care worker level. Thus, a lack of understanding of the value context means that there are no guarantees that the technology will even be adopted or adapted; if it does not make sense or seems to collide with the ethical demands and experiences, care workers may choose not to implement new methods into their daily practice. This has, however, not been the direct object of study in the research of this article, which has focused more on processes of innovation in a care work setting and less on communities of practice. Thus, these results can merely be indicated based on insights into innovation processes and knowledge shared as reported in the case. This could potentially be a subject for future research. 


\section{Conclusion}

This article has discussed the conditions for dissemination of innovation across organizations in elder care in the municipality of Copenhagen. This has been discussed by investigating the knowledge and rationality at play in daily practice and innovation processes in care work in nursing homes. The article argues that understanding the knowledge and rationality at play in innovation processes is key to understanding conditions for the dissemination of innovation in care work, as the local context and identity is important for participants' willingness to adopt innovations. It elucidates the interrelationship between the contextual and relational character of formal paid care work and more systematic, formal and codified types of knowledge, while the analysis illustrates how various types of knowledge and reasoning are relevant to care practice. The work with innovations in the case study involves an interplay between formal, explicit types of knowledge and situated, contextual knowledge of care. In this sense, the analysis of the article represents a break from an overly dichotomous view on care and competence, and it stresses that care rationality stands alongside other, more formal types of knowledge and rationality. The caring competence of reading the citizen and his or her needs in a particular moment, formal scientific knowledge about dementia, as well as an understanding of formal rights to due process are all central for the situations of care that employees portray as successful. The innovation project represents ways to systematize and formalize dimensions of care in ways that make it possible to talk, explicate and share experiences about care situations with particular citizens. The deep anchoring in local practice is emphasized as an important factor for the innovation project and its activities to be experienced as meaningful to the employees. They also express that adoption of innovations from other nursing homes would only be interesting if they fit into the local practices and experienced needs of citizens and, furthermore, that it would involve a great deal of adaption. In that sense, the article contributes to existing research on diffusion of innovation in the public sector by providing a concrete example of practices related to innovation and adaption in the domain of elder care. Based on the statements of care workers concerning how knowledge is developed and shared, the article has argued that communities of practice may be seen as a key concept pertaining to the processes and diffusion of innovation in care. The implications for practice are that there is a need for increased awareness and acknowledgement of how important the different types of rationality, including situated and relational care rationality, are for practices in elder care and for identities of care workers.

\section{Acknowledgements}

The author would like to thank Anne Vorre Hansen for comments and for collaboration on earlier versions of this article.

\section{References}

Bacchi, L. C., \& Beasley, C. (2002). Citizen bodies: Is embodied citizenship a contradiction in terms? Critical Social Policy, 22(2), 324-62. https://doi.org/10.1177/02610183020220020801

Bason, C. (2007). Velfærdsinnovation: ledelse af nytænkning i den offentlige sektor. København: Børsen. 
Brown, J. S., Collins, A., \& Duguid, P. (1989). Situated cognition and the culture of learning. Educational Researcher, 18(1), 32-42. https://doi.org/10.3102/0013189X018001032

Brown, J. S., \& Duguid, P. (1991). Organizational learning and communities-ofpractice: Toward a unified view of working, learning and innovation. Organization Science: Special Issue: Organizational Learning: Papers in Honor of (and By) James G. March, 2(1), 40-57. https://doi.org/10.1287/orsc.2.1.40

Dahl, H. M. (2009). New public management, care and struggles about recognition. Critical Social Policy, 29(4), 634-54. https://doi.org/10.1177/0261018309341903

Dahl, H. M. (2012). "Omsorg, Styring og Køn Gennem Tavshed og Italesættelse." Kvinder, Køn \& Forskning no. 3, 52-59.

Dahl, H. M., \& Rasmussen, B. (2012). Paradoxes in elderly care: The Nordic model. In A. Kamp \& H. Hvid (Eds.), Elderly care in transition: Management, meaning and identity at work. A Scandinavian perspective (pp. 29-49). Copenhagen: Copenhagen Business School Press.

Daly, M., \& Lewis, J. (2000). The concept of social care and the analysis of contemporary welfare states. British Journal of Sociology, 51(2), 281-98. https://doi.org/10.1111/j.1468-4446.2000.00281.x

Davies, C. (1995). Competence versus care? Gender and caring work revisited. Acta Sociologica, 38(1), 17-31. https://doi.org/10.1177/000169939503800103

De Jong, J. P. J. \& Vermeulen, P. A. M. (2003). Organizing successful new service development: A literature review. Management Decision, 41(9), 844-58. https://doi.org/10.1108/00251740310491706

Du Gay, P. (2008). 'Without affection or enthusiasm' problems of involvement and attachment in 'responsive' public management. Organization, 15(3), 335-53. https://doi.org/10.1177/1350508408088533

Dybbroe, B. (2012). The meaning of work from subjective and intersubjective perspectives - a daily conflict of creating and losing meaning in elderly care. In A. Kamp \& H. Hvid (Eds.), Elderly care in transition: Management, meaning and identity at work. A Scandinavian perspective (pp. 131-64). Frederiksberg: Copenhagen Business School Press.

Eriksen, E. O. (1999). Kommunikativ ledelse: Om styring af offentlige organisationer. Fakbokforlaget: Bergen.

Fine, M., \& Glendinning, C. (2005). Dependence, independence or inter-dependence? Revisiting the concepts of 'care' and 'dependency'. Ageing \& Society, 25, 60121. https://doi.org/10.1017/S0144686X05003600

Friedman, M. (1995). Beyond caring: The de-moralization of gender. In V. Held (Ed.), Justice and care: essential readings in feminist ethics (pp. 61-77). Colorado US and Oxford UK: Westview Press.

Fuglsang, L. (2008). "Balancen mellem ledelse og bricolage: ledelsesdilemmaer i bæredygtig offentlig innovation." Paper til Det Danske ledelsesakademis 3. konference, Clarion Hotel, København, d. 8.-9. december.

Fuglsang, L., \& Rønning, R. (2014). Introduction - framing innovation in public service sectors: A contextual approach. In L. Fuglsang, R. Rønning \& B. Enquist (Eds.), Framing innovation in public service sectors (pp. 1-17). New York and London: Routledge. 
Fuglsang, L., \& Sørensen, F. (2011).The balance between bricolage and innovation: Management dilemmas in sustainable public innovation. The Service Industries Journal, 31(4), 581-95. https://doi.org/10.1080/02642069.2010.504302

Gilligan, C. (2009). In a different voice. Cambridge, Mass: Harvard University Press.

Habermas, J. (1990). "Moral, samfund og etik: Et interview ved Torben Hviid Nielsen. Politica Bind 22, Det civile samfund, 224-247.

Hartley, J. (2005). Innovation in governance and public services: Past and present. Public Money and Management, 25(1), 27-34.

Hartley, J. (2016). Organisational and governance aspects of diffusing public innovation. In J. Torfing P. Triantafilou (Eds.) Enhancing public innovation by transforming public governance (pp. 71-94). Cambridge: Cambridge University Press.

Hartley, J., \& Benington, J. (2006). Copy and paste, or graft and transplant? Knowledge sharing through inter-organizational networks. Public Money \& Management, 26(2), 101-8. https://doi.org/10.1111/j.1467-9302.2006.00508.x

Held, V. (1995). Introduction. In V. Held (Ed.), Justice and care: Essential readings in feminist ethics (pp. 61-77). Colorado US and Oxford UK: Westview Press. https://doi.org/10.1016/0272-6386(95)90075-6

Kamp, A., \& Hvid, H. (2012). Introduction: Elderly care in transition. In A. Kamp \& H. Hvid (Eds.), Elderly care in transition: Management, meaning and identity at work. A Scandinavian perspective (pp. 13-28). Frederiksberg: Copenhagen Business School Press. https://doi.org/10.1057/9780230348202 1

Knijn, T., \& Kremer, M. (1997). Gender and the caring dimension of welfare states: Towards inclusive citizenship. Social Politics, Fall, 328-61. https://doi.org/10.1093/oxfordjournals.sp.a034270

Kröger, T. (2009). Care research and disability studies: Nothing in common? Critical Social Policy, 29(3), 398-420. https://doi.org/10.1177/0261018309105177

Krøjer, J., \& Dupret, K. (2015). Moral literacy in technological care work. Ethics and Social Welfare, 9(1), 50-63. https://doi.org/10.1080/17496535.2014.938672

Kvale, S. (2007). Interview - En introduktion til det kvalitative forskningsinterview. København: Hans Reitzels Forlag.

Langergaard, L. L. (2011). Innovating the publicness of the public sector. Roskilde: Roskilde University Press. http://forskning.ruc.dk/site/services/downloadRegister/35980324/xThesis Lange rgaard.pdf.

Moltesen, J., \& Dahlerup, S. (2007). Dekoblingspolitik: visioner og initiativer i den danske regerings innovationspolitik. København: Institut for Statskundskab, Københavns Universitet.

Morris, J. (1997). Care or empowerment? A disability rights perspective. Social Policy \& Administration, 31(1), 54-60. https://doi.org/10.1111/1467-9515.00037

Morris, J. (2001). Impairment and disability: Constructing and ethics of care that promotes human rights. Hypatia, 16(4), 1-16. https://doi.org/10.1111/j.15272001.2001.tb00750.x

Nonaka, I. (1994). A dynamic theory of organizational knowledge creation. Organization Science, 5(1), 14-37. https://doi.org/10.1287/orsc.5.1.14 
Okin, S. M. (1989). Reason and feeling in thinking about justice. Ethics, 229-49. https://doi.org/10.1086/293064

Parton, N. (2003). Rethinking professional practice: The contributions of social constructionism and the feminist 'ethics of care'. British Journal of Social Work 33, 1-16. https://doi.org/10.1093/bjsw/33.1.1

Rådet for Teknologi og Innovation. (2008). "Strategi for styrket innovation i den offentlige sektor." ufm.dk/publikationer/2008/strategi-for-Styrket-Innovation-IDen-Offentlige-Sektor.

http://ufm.dk/publikationer/2008/filer-2008/strategi-for-styrket-innovation-i-denoffentlige-sektor.pdf.

Rogers, E. M. (1995). Diffusion of innovations. Fourth Edition. New York, US: The Free Press.

Rothstein, B. (1998). Just institutions matter: the moral and political logic of the universal welfare state. Cambridge: University Press. https://doi.org/10.1017/CBO9780511598449

Sundbo, J., \& Toivonen, M. (2011). Introduction. In J. Sundbo \& M. Toivonen (Eds.), User-based innovation in services (pp. 1-21). Cheltenham, UK and Northhampton, MA, USA: Edward Elgar.

Tanggaard, L., \& Wegener, C. (2015). Why novelty is overrated. Journal of Education and Work, 1-18.

Toivonen, M. (2010). Different types of innovation processes in services and their organizational implications. In F. Gallouj \& F. Djellal (Eds.), The handbook of innovation and services - A multidisciplinary perspective (pp. 221-48). Cheltenham, UK, Northampton MA, USA: Edward Elgar Publishing. https://doi.org/10.4337/9781849803304.00021

Wærness, K. (1984). The rationality of caring. Economic and Industrial Democracy, 5 , 185-211. https://doi.org/10.1177/0143831X8452003

Wenger, E. (2000). Communities of practice and social learning systems. Organization, 7(2), 225-46. https://doi.org/10.1177/135050840072002

Young, I. M. (1989). Polity and group difference: A critique of the ideal of universal citizenship. Ethics, 99(2), 250-74. https://doi.org/10.1086/293065 